\title{
Usrah Approach of Drug Addiction Treatment in a Fishermen Community: Psychology of $D a$ 'wah Perspective
}

\author{
Wan Hanis Aisyah Wan Rosdi ${ }^{1}$, Zawawi Yusoff ${ }^{1}$, Nasir Mohamad ${ }^{1}$, Shafie Hamzah ${ }^{1}$, Siti Anis Nuraida Masaud ${ }^{1}$ \\ ${ }^{1}$ Universiti Sultan Zainal Abidin (UniSZA), Kampus Gong Badak, 21300 Kuala Nerus, Terengganu, Malaysia \\ Correspondence: Wan Hanis Aisyah Wan Rosdi. E-mail: hanisaisyah30@yahoo.com.my
}

Received: November 29, 2018

Accepted: December 7, 2018

Online Published: January 30, 2019

doi:10.5539/ass.v15n2p142

URL: https://doi.org/10.5539/ass.v15n2p142

\begin{abstract}
The Psychology of da'wah (making an invitation) is part of the Islamic psychology approach based on the Al-Quran and Al-Sunnah. Da'wah in terms is invites people to do something benefit and abstain from evil. Psychology of da'wah is a part used in the treatment and rehabilitation of drug addiction to the drug addict. This article discusses the usrah (a meeting involving Islamic religious activities) approach as a means of assisting drug addict in fishermen communities to reduce addiction. The method used in this article is a qualitative study of past documentary literature review analysis and library document analysis. The result of the previous studies show that the psychology of da'wah through the usrah approach is one of the method to implement for rehabilitate the drug addict who ia a muslim. This is because this approach ia a based on Islamic teachings which has been implemented by the Messenger Muhammad Pbuh.
\end{abstract}

Keywords: psychology of $d a^{\prime}$ wah, drug addict, fishermen, Islamic teachings, usrah

\section{Introduction}

The fishermen community in Malaysia is a group of people who carry out marine harvesting activities either through modern or traditional methods (Zaimah et al., 2015). Their dependence on marine has let them to less chance of developing life and increasing revenue. Moreover, it brings them to an eternal poor life (Sa'at, 2011). The poverty and low educational level is a one of factor that the fishermen's community to be susceptible in drug addiction (Ismail et al., 2017). The fishermen's community is a poor, low-income community and is marginalizes from modern society groups (Sa'at, 2011). Due to the poverty factor, the society in this community is vulnerable to social problems such as drug addiction (Ismail et al., 2017). According to Colman (2015), drug addict in fishermen communities are high-risk group with HIV infection in Malaysia. This is because the fishermen are vulnerable groups with unhealthy activities due to lack of knowledge regarding social problems (Shamsudin \& Mohamed, 2013). There is no doubt that fishermen are their cultural but in modern times these external influences have become a major cause for the problem of drug addiction among fishermen until they gradually affected in the drug addiction problem (Fischer, 2015).

Addiction is a big issue today's in society. According to Mohammad Aziz Shah et al. (2013) addiction is a high desire for something. According to Khairunneezam Mohd. Noor et al. (2015) addiction is an uncontrolled desire by an individual towards something that cause physical harm to the soul. Additionally, drug addict from medical point of view refers to a person who relies on the use of substances that can cause addiction. The addictive effect to individuals is a change of their emotions and behaviors and will detrimental effect to the addictive substances, they may experience adverse effect on the body such as nausea and vomiting, fear, muscle aches, fever, difficulty in sleep and diarrhea (American Psychiatric Association, 2016). As noted by Lua Pei Lin \& Nor Samira (2012) if addiction in not treated the addict will be physically and psychological dependent such as causing symptoms or withdrawal and experiencing 'longing' to use drugs continuously.

In Malaysia, there are various addictive treatments that have been implemented such as the construction of the government, private centers and rehabilitation center (Ismail, 2010). Among the successful treatment and rehabilitation on that has been well executed is through a spiritual approach as the treatment strategy implemented in 'Pondok Inabah' (Aishah et al., 2013). The spiritual approach used in the 'Pondok Inabah' for treating addiction is to cleanse the soul through obligatory worship, repentance concept, dhikir prayer, guidance of Quran and fardhu ain (comulsory things) (Ghani \& Adam, 2014). Therefore, this article will examine the addiction treatment with the usrah approach from a psychological perspective of $d a$ 'wah that can be used to help 
people with drug problem especially among fishermen.

\section{Psychology Concept}

Psychology in terms is in the study of the mind (mental process) and thinking is a one of the main mental process (Colman, 2015). In Malaysia, a psychology of da'wah approach through a counseling program has been implemented to restore addiction to drug rehabilitation centers (Mustaffa, Ahmad, \& Kadir, 2006). Psychological treatment help the addict to have an optimistic thinking of the future, have high self-control, risk-taking ability and have the ability to handle stress (Ibrahim et al., 2009). Among the psychological approaches used in drug rehabilitation centers in the recovery of addiction is to train them to hate drugs, find other ways to replace drugs, strengthen the desire to stay from drugs and manage stress without taking (Ismail et al., 2017). This psychological method is important to be practiced by all Muslims in carrying out $d a$ 'wah activities for those who slipped from the Islamic foundation (Ibrahim et al., 2009).

\section{Da'wah Concept}

Da'wah in the term intends to bring about good by making changes to a better situation in all aspects of life based on the true teachings of Islam (Hanan, 2016). Based on the development of Messenger Muhammad Pbuh mission history, he has carried out da'wah activities by inviting the Jahiliyyah's people toward Allah (Ishak, 2011). Among the da'wah approaches used by Messenger Muhammad Pbuh in delivering da'wah to the Jahiliyyah's people in Makkah was to initiate da'wah activities in hiding at the Al-Arqam Bin Abi Al-Arqam house while the Messenger Muhammad Pbuh selivered the first da'wah in secret at Makkah. At the time, the Messenger Muhammad Pbuh only preached to the family, friends, salves and children (Kusumawati, 2016). Now, the methodology of da'wah is still being carried out by Islamic organizations and is applied in the spiritual programs by usrah groups (Mokhtar et al., 2017).

\section{Usrah Concept}

Usrah can be defined as a method to develop individuals in a planned a gradual manner based on certain goals as an effort to solve the problem if ummah (Muslim's) practically and sunnah including the condition of the ummah in terms of their fikrah or thinking (Mustari and Salleh, 2010). The effective ways of implementing usrah will be able to guide the Muslim, strengthen the $u k h w a h$ (family bond) (Gordani \& Don, 2017).

Hence, this usrah approach is important to help drug addicts become real Muslims because the religious approach is the best way to guide their souls so as not return to take the drug (Adabi et al., 2010). Therefore, the usrah concept was important because the approach of Islamic religious is the best way to give the souls so as not return to the drug addiction (Muhamad et al., 2015). Next, according to Siti Norlina Binti Muhamad et al. (2015) the main thing in this concept of drug addict is to create awareness and strength to change their self in a better direction. Besides, the drug addict will be able to better understand the religion of Islam and strive to keep away from drug.

\section{Psychology of Da'wah in the Usrah}

From the discussion above the psychology of $d a^{\prime}$ wah is a combination of two concepts namely psychology and da'wah. According to Faizah, Effendi \& H. Lalu Muchsin (2006), psychology of $d a$ 'wah is the science that studies that studies the symptoms of human psychological life involved in the process of $d a$ 'wah activities. Thus, usrah a one of the da'wah by combining the psychological concept in three main transmission of the usrah such as taaruf (introduction), tafahum (understanding) and takaful (accessbility help) (Sham \& Nazim, 2015). These three methods serve as a guideline in providing a psychilogical approach to $d a$ 'wah to help drug addict strengthen themselves and stay together with their groups who have the same limitations, situations and experiences with each other among group of usrah itself (Husin \& Othman, 2010).

\section{Ta'aruf (Introduction)}

Ta'aruf means introduction and become the first method in usrah to create a brotherhood relationship by knowing ourselves and members of the usrah group (Sham \& Nazim, 2015). The drug addict needs to feel brotherhood between one another and they are prohibited to create a senario that can affect the situation within the group (Sham, Ibrahim, \& Endot, 2000). The concept helps them to feel brotherhood bonds based on affection for one another because the addicts are often marginalized people and their families (al-Azhari, 2009).

\section{Tafahum (Understanding)}

According to Fariza Md Sham \& Azyyati Mohd Nazim (2015) understanding or tafahum in the form of reconciliation refers to the understanding among members in the group of usrah, which is to accept the advantages and disadvantages of the members. Once an understanding exists, members of the usrah group can 
interact well with each other in the group during the implementation of the program. The usrah's members can give opinion, advice and even the reprimad, thus giving birth to love and affection between them. The addicts needs strength and persistent social support from groups such as family members, neighbors and communities to recover from being addicted (Mohamed, 2006). It is supported by Fariza Md Sham \& Azyyati Mohd Nazim (2015) that the tafahum concept in the group of usrah can be strengthening the sense of bonding of the brotherhood. This method can also help the addicts continue to change and start a new life.

\section{Takaful (Accessibility Help)}

The third metod according to Fariza Md Sham \& Azyyati Mohd Nazim (2015) takaful is a helping concept without allowing members or the usrah group to bear im facing the challenges of life. The drug addicts are the ones that need to be assisted by the individuals who are around it while undergoing an rehabilitation treatment. Without support and help, it is likely that recovered drug addicts will return to the relapse (Fauziah Ibrahim e. al., 2009). Members of the usrah group are not only together and understand the addicts, but are also willing to help without tears in the addiction recovery process (Jusoh et al., 2015). The takaful approach is recommended in any treatment and rehabilitation (Kaur, Mohd, \& Nazar, 2009). This is because they need the support of individuals who are ready to help in continuing their efforts to recover from addiction and remain in existing programs (Tunggak et al., 2015). The previous research by Buerah Tunggak et al. (2015) shows that every member of usrah cares about all his other by the visiting practices and helping during any difficulty. Therefore, takaful plays a role for every members work togather in group and give support such as motivation, financial assistance, protection, advice, joint responsibility to continue their efforts to and continue the treatment (Ibrahim et al., 2009).

\section{Methods of Appreciating the Psychology of Da'wah in the Usrah}

This method allows us to inviting drug addicts to believe in God and surrender the life of the world regardless of the circumstances. It can be seen in three dimensions:

First: The appreciation of Islamic $d a$ 'wah through the usrah approach can be presented wisely to the drug addicts return to the path he approves (Muhamad et al., 2015).

Second: The teaching through the usrah approach is more readily understood and practiced in life because it not only understands the members of the group but also willingly helps towards a better process (Dardaa et al., 2014).

Third: Third: Da'wah dakwah gradually through usrah approach can increase the conviction and taqwa from the addict to Allah, encouraging them to keep them from being addicted (Sham \& Nazim, 2015).

\section{Conclusion}

This article discusses the usrah approach to drug addicts is one of the processes that can be used to restore addiction. In addition, the psychology of da'wah is also applied in usrah to guide a person to behave well and encourage them to strive to be good Muslims. Psychological approaches in da'wah are also applied in the usrah approach to realizing the feeling of being a good person, helping and transforming them in a better way. The psychological approach of da'wah in usrah is also used to preserve them and continue treatment of drug addiction to prevent them from being trapped again in drug addiction as before. In addition, the method used in usrah is dependent on the counselor's presentation to other members in usrah by giving advice, giving guidance, always commemorating our efforts to always do good deeds and strive to abandon something that is not allowed by religion. In addition they also need to educate members of usrah in maintaining human relationships. Counselors also need to show a good example for usrah as a guide to them. The da'wah psychological approach is very important for drug addicts to avoid and not repeat past mistakes.

\section{References}

Adabi, F. et al. (2010). Usrah Teras Pembangunan Insan: Tinjauan Pelaksanaannya Dalam Kalangan Para Pelaar Kolej Islam Sultan Alam Shah (KISAS). Jurnal Usuluddin, 77-94.

Aishah, D. et al. (2013). Drug Addict Treatment And Rehabilitation Programme At Pondok Inabah, Kuala Terengganu, Terengganu Malaysia (1998- 2011). British Journal Of Social Science, 1(5), 37-46.

al-Azhari, B. I. al-H. (2009). Psikologi Rasulullah s.a.w: Dalam Berinteraksi Dengan Masyarakat. Batu Caves: Al- Hidayah Publication.

American Psychiatric Association. (2016). Diagnostic and Statistical Manual Of Mental Disoder (5th ed.). America: American Psychiatric Association. 
Colman, A. M. (2015). A dictionary of psychology (4th ed.). Oxford: Oxford University Press.

Colman, A. M. (2015). Oxford Dictionary of Psychology. United Kingdom: Oxford University Press.

Dardaa, A. et al. (2014). Cabaran Dakwah Islamiah Dan Masalah Perapi Di Sarawak. Universiti Kebangsaan Malaysia, 1-18.

Faizah, E., \& Lalu Muchsin, H. (2006). Psikologi Dakwah. Kota Mataram: Kencana.

Fischer, J. A. (2015). Beyond Pleasure: A study into the quality of life of drug users (Thesis).

Ghani, S. A., \& Adam, F. (2014). Pemulihan Dadah Menurut Persepktif Agama Di Malaysia. Jurnal Hadhari, 75-85.

Gordani, N. B., \& Don, A. G. B. (2017). Sukatan Usrah Dalam Membentuk Akhlak Mulia: Kajian Di Maahad Tahfiz Wal Tarbiyyah Darul Iman (Satu Dapatan Awal).

Hanan, F. (2016). Uslub Dakwah Menurut Perspektif Islam. Seminar Antarabangsa Akidah, Dakwah Dan Syariah (Irsyad 2016) (pp. 69-84). Selangor: KUIS.

Husin, H., \& Othman, M. H. (2010). Keperluan Pendekatan Kaunseling Kelompok Terapeutik Terhadap Penagih Dadah. Bimbingan Dan Kaunseling, 63-71.

Ibrahim, F. et al. (2009). Faktor Menyumbang Kepada Penagihan Relaps Dalam Kalangan Penagih Dadah PUSPEN Di Semenanjung Malaysia. Jurnal AADK, 1-17.

Ishak, S. (2011). Model Kepemimpinan Etika Berlandas Sirah Nabi Muhammad Saw. Jurnal Hadhari, 23-44.

Ismail, R (2010). Pemerkasaan Pengguna Dadah Dalam Institusi Pemulihan Di Malaysia: Ke Arah Menjamin Kesejahteraan Individu Dan Masyarakat. UKM Journal Respiratory, 31-49.

Ismail, R. et al. (2017). Pengaruh Faktor Individu, Keluarga Dan Persekitaran Sosial Terhadap Tingkah Laku Penyalahgunaan Bahan Dalam Kalangan Remaja. Journal of Southeast Asia Social Scince and Humanities, $1-10$.

Jusoh, M. R. et al. (2015, December). Keberkesanan Terapi Kelompok Psikopendidikan Dalam Meningkatkan Motivasi Penagih Dadah. Jurnal Anti Dadah Malaysia, 9(1), 1-18.

Kaur, S., Mohd, H. Bt., \& Nazar, M. (2009). Projek Perintis Program Rawatan Terapi Gantian (RTG) Menggunakan Methadone Di Pusat Khidmat AADK. Jurnal AADK, 1-30.

Kusumawati, Z. (2016). Peran hisbah dalam mekanisme pasar Islami. Islamic Economics Journal, 245-259.

Lin, L. P., \& Samira, N. (2012). Terapi Gantian Metadon Untuk Penagihan Dadah. Terengganu: Penerbit UniSZA. Terengganu: Penerbit UniSZA.

Mohamed, A. (2006). Tingkahlaku Penagihan Semula Punca-Punca Penagihan Dan Pemulihan Kerohanian Menurut Perspektif Islam. Johor: Universiti Teknologi Malaysia.

Mokhtar, A. E. et al. (2017). Dakwah Kepada Golongan Profesional Di Pahang. Jurnal Perspektif, 136-148.

Muhamad, S. N. B. et al. (2015). Keberkesanan Rawatan Pemulihan Dadah Menggunakan Pendekatan Keagamaan: Kajian Dalam Kalangan Pelatih Wanita Di CCRC Bachok (Kelantan), AADK Besut, AADK Kemaman Dan CCSC Kuala Terengganu (Terengganu). Jurnal Antidadah Malaysia, 1-16.

Mustaffa, M. S., Ahmad, R., \& Kadir, H. A. (2006). Teori Dan Praktis Kunseling Kelompok Kontemporari. Skudai, Johor: Penerbit UTM.

Noor, K. M. et al. (2015). Tahap Perubahan Klien Selepas Menjalani Rawatan, Perubatan Dan Pemulihan Di Klinik C\&C1M. International Drug Prevention And Rehabilitation Conference, 83-97.

Sa'at, N. H. (2011). Mobiliti Sosial Dalam Kalangan Komuniti Pesisir Pantai : Kajian Kes Di Kuala Terengganu. Kajian Malaysia, 95-123.

Shah, M. A. et al. (2013). Strategi Menangani Ketagihan Penggunaan Facebook Dalam Kalangan Pelajar Sekolah Menengah. Jurnal Personalia Pelajar, 93-103.

Sham, F. bt. M., Ibrahim, S., \& Endot, I. (2000). Dakwah Dan Perubahan Sosial. Kuala Lumpur: Utusan Publications \& Distributors.

Sham, F. M., \& Nazim, A. M. (2015). Pendekatan Psikologi Dakwah Dalam Menangani Remaja Berisiko: Fokus Pendekatan Bimbingan Jiwa. Jurnal Hadhari, 63-73.

Sham, F. M., Ibrahim, S., \& Endot, I. (2000). Dakwah Dan Perubahan Soial. Kuala Lumpur: Utusan 
Publication.

Shamsudin, S. A., \& Mohamed, A. @ E. H. (2013). Merungkai Beberapa Faktor Jangkitan HIV / AIDS Dalam Kalangan Penagih Dadah Mengikut Perspektif Sosiobudaya. Jurnal Islam Dan Masyarakat, 49-63.

Tunggak, B. et al. (2015). Faktor Risiko Belia Terlibat Dalam Penyalahgunaan Dadah dan Cadangan Penyelesaiannya Menerusi Model Pembangunan Belia Muslim Terpimpin. Jurnal Antidadah Malaysia.

Zaimah, R. et al. (2015). Kesejahteraan Subjektif: Kajian Kes Nelayan Di Sedili, Kota Tinggi, Johor. Malaysia Journal of Society and Space, 87-94.

\section{Copyrights}

Copyright for this article is retained by the author(s), with first publication rights granted to the journal.

This is an open-access article distributed under the terms and conditions of the Creative Commons Attribution license (http://creativecommons.org/licenses/by/4.0/). 